\title{
Wpływ biostymulatorów na plon i jakość bulw ziemniaka uprawianego w warunkach suszy i wysokiej temperatury
}

\author{
The effect of biostimulators on the yield and quality of potato tubers grown \\ in drought and high temperature conditions
}

\section{Cezary Trawczyński}

\author{
Zakład Agronomii Ziemniaka, Instytut Hodowli i Aklimatyzacji Roślin - Państwowy Instytut Badawczy, \\ Oddział w Jadwisinie, \\ $\triangle$ c.trawczynski@ihar.edu.pl
}

\begin{abstract}
W latach 2018 - 2019 przeprowadzono na glebie lekkiej badania polowe nad określeniem wpływu dolistnego dokarmiania roślin ziemniaka biostymulatorami: Krzemian (preparat krzemowy), Naturamin Plus i Naturamin WSP (preparaty aminokwasowe) na plon i jakość bulw ziemniaka. W każdym roku wykonywano dwa zabiegi dolistnego dokarmiania w fazach BBCH 19 i 39 (preparatami Naturamin Plus i Naturamin WSP) oraz 39 i 70 (preparatem Krzemian). Kontrolę stanowił obiekt bez dolistnego dokarmiania i stosowania wody. Nawożenie organiczne stanowiły przyorywane każdego roku: słoma z pszenżyta ozimego i zielona masa międzyplonu z gorczycy białej. Nawożenie mineralne stosowano w dawkach: $100 \mathrm{~kg} \cdot \mathrm{ha}^{-1} \mathrm{~N}, 26,2 \mathrm{~kg} \cdot \mathrm{ha}^{-1} \mathrm{P}$ i $99,6 \mathrm{~kg} \cdot \mathrm{ha}^{-1} \mathrm{~K}$. Pod wpływem zastosowanych preparatów uzyskano w badaniach zbliżony przyrost plonu bulw, większy o 17,3\% w porównaniu do kontroli. Większy przyrost plonu bulw pod wpływem preparatów uzyskano w 2018 roku, o mniejszym niedoborze opadów i wyższej temperaturze powietrza, niż w 2019 roku. Pod wpływem zastosowanych preparatów uzyskano istotny wzrost zawartości skrobi, suchej masy i witaminy $\mathrm{C}$ w bulwach, a preparat Krzemian spowodował obniżenie poziomu azotanów (V) w bulwach w porównaniu do obiektu kontrolnego.
\end{abstract}

Słowa kluczowe: biostymulatory, jakość bulw, plon, warunki pogodowe, ziemniak

In the years 2018 - 2019, field trials were carried out on light soil on the effect of foliar fertilization of potato plants with biostimulators: Krzemian (silicon preparation), Naturamin Plus and Naturamin WSP (amino acid preparations) with regard to the yield and quality of potato tubers. Each year, two foliar fertilization treatments were carried in $\mathrm{BBCH}$ 19 and 39 phases - Naturamin Plus and Naturamin WSP preparations, and 39 and 70 - silicate preparation. The control was without foliar fertilization, water being used instead. The soil was amended each year by incorporating through ploughing, straw from winter triticale and green intercrop from white mustard, while mineral fertilization was applied in the following doses: $100 \mathrm{~kg} \cdot \mathrm{ha}^{-1} \mathrm{~N}, 26.2 \mathrm{~kg} \cdot \mathrm{ha}^{-1} \mathrm{P}$ and $99.6 \mathrm{~kg} \cdot \mathrm{ha}^{-1} \mathrm{~K}$. Under the influence of the preparations used in the studies, a similar increase in tuber yield was obtained, higher by $17.3 \%$ compared to the control. A greater increase in tuber yield under the influence of preparations was obtained in the year of 2018, with less rainfall deficiency and higher air temperature than in the year of 2019. Under the influence of the preparations used, a significant increase in the content of starch, dry matter and vitamin $\mathrm{C}$ in tubers was obtained, but the preparation of Krzemian caused a decrease in the level of nitrates (V) in tubers, compared to the control.

Key words: biostimulators, quality of tubers, yield, weather conditions, potato

\section{Wstęp}

Zapobieganie niekorzystnemu przebiegowi pogody na wegetację roślin oraz aktywacja naturalnych systemów obronnych, stymulujących ich wzrost i rozwój powinny stanowić podstawę działań profilaktycznych w nowoczesnych, proekologicznych technologiach produkcji ziemniaka (Rykaczewska 2013, Sharma i in. 2014). Jednym ze sposobów poprawy kondycji roślin w warunkach niekorzystnego układu warunków pogodowych, a przez to uzyskiwania odpowiednio wysokiego plonu i właściwej jakości bulw może być dolistne dokarmianie roślin preparatami zawierającymi związki bioaktywne i szybko przyswajalne formy składników pokarmowych (Erlichowski i Pawińska 2003, Trawczyński 2013, Wierzbowska i in. 2015). Stąd biostymulatory budzą coraz większe zainteresowanie producentów różnych gatunków roślin rolniczych, w tym ziemniaka. Produkty te poprzez rodzaj pochodzenia i wytwarzanie w różnych technologiach klasyfikuje się obecnie na kilka klas (Du Jardin 2015). Z uwagi na zróżnicowanie technologiczne i obecność w składzie różnych pierwiastków i substancji bioaktywnych działanie tych preparatów zależeć może od specyfiki poszczególnych 
gatunków roślin. Oznacza to, że w przypadku jednych gatunków może być korzystne, a w odniesieniu do innych nie przynosić pożądanych efektów, co wynikać może z wrażliwości roślin na określone cząsteczki bioaktywne (Ertani i in. 2011). Dlatego coraz szerszy asortyment pojawiających się na rynku produktów biostymulujących, skłania do oceny, szczególnie tych, o deklarowanym specyficznym i kompleksowym działaniu czy zawierających pierwiastki o nieokreślonych właściwościach. Jedną z takich grup stanowią biostymulatory aminokwasowe uzyskiwane $\mathrm{w}$ procesie hydrolizy enzymatycznej (Colla i in. 2015). Stymulować one mogą wzrost części nadziemnych oraz rozwój systemu korzeniowego, syntezę chlorofilu, wchłanianie substancji odżywczych z gleby czy metabolizm podstawowych pierwiastków (Popko i in. 2018)). Spośród pierwiastków działanie biostymulujące na różne gatunki roślin rolniczych może wykazywać zastosowany w odpowiedniej formie krzem (Mitani i Ma 2005, Raven 2003). W glebie występuje w postaci nieprzyswajalnej krzemion$\mathrm{ki}$, ale zastosowany $\mathrm{w}$ formie płynnej np. kwasu ortokrzemowego na rośliny impregnować może zewnętrzne komórki epidermy, wzmacniać ściany komórkowe, zwiększać ich sztywność i odporność na uszkodzenia mechaniczne (Sommer $i$ in. 2006). Grubsza kutikula wysycona krzemem ograniczać może straty wody, a rośliny mniej porażane przez choroby grzybowe i szkodniki (Fauteuxi in. 2005, Romero-Aranda i in. 2006, Sacała 2009). Dotychczasowe badania potwierdziły korzystne oddziaływanie na plon i jakość krzemu w formie różnego rodzaju preparatów stosowanych na rośliny dwuliścienne, w tym okopowe (Artyszak i in. 2016) oraz warzywne (Górecki i Danielski-Busch 2009, Stamatakis $i$ in. 2003, Ugrinović i in. 2011), co skłoniło do przeprowadzenia określonych badań w stosunku do ziemniaka. Dodatkowo w nawiązaniu do powyższych argumentów, silna zależność plonu i jakości bulw ziemniaka od warunków pogodowych predysponowała do przeprowadzenia określonych badań, szczególnie przy ekstremalnym ich układzie w okresie wegetacji roślin.

Stąd celem badań była ocena oddziaływania na wielkość plonu i wybrane cechy jakości bulw nowych biostymulatorów aminokwasowych oraz krzemu, zastosowanych na rośliny ziemniaka uprawiane $\mathrm{w}$ latach $\mathrm{z}$ niedoborem opadów i wysoką temperaturą powietrza.

\section{Material i Metody}

Badania polowe przeprowadzono w latach 2018 - 2019 w IHAR-PIB oddział w Jadwisinie $\left(52^{\circ} 45^{\prime} \mathrm{N}, 21^{\circ} 63^{\prime} \mathrm{E}\right)$ na glebie zaliczanej do rzędu płowoziemnych, typu gleby płowe, podtypu gleby płowe opadowo glejowe (Marcinek i in. 2011). Gleba charakteryzowała się kwaśnym odczynem, wysoką zasobnością w przyswajalny fosfor, średnią w potas, mangan, cynk, miedź i bor oraz niską w magnez (tabela 1).

Doświadczenia zakładano w układzie losowanych bloków w trzech powtórzeniach. Wielkość poletka wynosiła $18,6 \mathrm{~m}^{2}$. W badaniach zastosowano preparaty biostymulujące: Krzemian z krzemem i mikroelementami oraz Naturamin Plus i Naturamin WSP - z zawartością aminokwasów pozyskanych z roślin wysokobiałkowych. Preparaty aminokwasowe: Naturamin Plus i Naturamin WSP zastosowano na rośliny ziemniaka $\mathrm{w}$ fazach BBCH 19 (zwieranie roślin ziemniaka w rzędach) i 39 (zwarcie roślin w międzyrzędziach), a preparat Krzemian w fazach BBCH 39 i 70 (po kwitnieniu roślin ziemniaka). Układ kombinacji był następujący: 1. Obiekt kontrolny - obiekt bez dolistnego dokarmiania i stosowania wody, 2. Krzemian $0,81 \cdot h^{-1}, 3$. Naturamin Plus $-1,51 \cdot h^{-1}, 4$. Natura$\min$ WSP $-0,5 \mathrm{~kg} \cdot \mathrm{ha}^{-1}$.

Skład zastosowanych w badaniach preparatów był następujący:

Krzemian - $\mathrm{Si}(\mathrm{OH}) 4-2,5 \%$; $\mathrm{Cu}-1,0 \%$; $\mathrm{Zn}-0,6 \%$; $\mathrm{B}-0,3 \% ; \mathrm{Mo}-0,2 \%$

Naturamin Plus - wolne aminokwasy $-32 \%$; $\mathrm{N}-6 \% ; \mathrm{Fe}-1 \% ; \mathrm{Mn}-0,6 \% ; \mathrm{Zn}-0,2 \%$; $\mathrm{B}-0,1 \%$; $\mathrm{Cu}-0,1 \% ; \mathrm{Mo}-0,047 \%$

Naturamin WSP - wolne aminokwasy - 80\%; $\mathrm{N}-12,8 \%$.

Do każdego zabiegu preparaty rozpuszczano w $3001 \cdot$ ha $^{-1}$ wody.

Warunki pogodowe $\mathrm{W}$ okresie wegetacji

Tabela 1

Table 1

Właściwości chemiczne gleby przed założeniem doświadczenia

Soil chemical properties before planting of experiment

\begin{tabular}{l|c|c|c|c|c|c|c|c|c}
\hline \multirow{2}{*}{$\begin{array}{c}\text { Lata } \\
\text { Years }\end{array}$} & $\begin{array}{c}\text { C organiczny \% } \\
\text { C organic \% }\end{array}$ & \multirow{2}{*}{$\begin{array}{c}\text { pH w KCl } \\
\text { pH in KCl }\end{array}$} & \multicolumn{7}{|c}{ Zawartość $\mathrm{mg} \cdot \mathrm{kg}^{-1} /$ Content $\mathrm{mg} \cdot \mathrm{kg}^{-1}$} \\
\hline 2018 & 0,88 & 5,4 & 84 & 104 & 26 & 118 & 4,0 & 4,3 & 1,32 \\
2019 & 0,66 & 5,2 & 75 & 100 & 22 & 91 & 5,2 & 4,9 & 0,94 \\
\hline
\end{tabular}


oceniono na podstawie sumy opadów i średnich temperatur powietrza $\mathrm{w}$ porównaniu do sum $\mathrm{i}$ wartości średnich z wielolecia. W 2018 roku wszystkie miesiące wegetacji charakteryzowały się opadami poniżej sumy $\mathrm{z}$ wielolecia, a temperaturą powietrza znacznie powyżej średniej z wielolecia. Suma opadów za cały okres wegetacji w 2018 roku była mniejsza o 79,2 mm, a średnia temperatura powietrza większa o $3,5^{\circ} \mathrm{C}$ w stosunku do sumy i wartości średniej z wielolecia. Na podstawie układu warunków pogodowych 2018 rok określono jako suchy i bardzo ciepły. Z kolei w 2019 roku, w głównych miesiącach wegetacji zanotowano większy niż w 2018 roku niedobór opadów oraz temperaturę powietrza przekraczającą średnią z wielolecia. Deficyt opadów za cały okres wegetacji w 2019 roku wyniósł135,6 mm, a temperatura powietrza większa była o $2,3{ }^{\circ} \mathrm{C}$ w stosunku do średniej z wielolecia. Stąd 2019 rok scharakteryzowano jako bardzo suchy i ciepły (tabela 2).

Nawożenie organiczne stanowiła rozdrobniona i przyorywana po żniwach słoma pszenżyta ozimego w ilości około 5 thaa $^{-1} \mathrm{z}$ dodatkiem $1 \mathrm{~kg} \mathrm{~N}$ na $100 \mathrm{~kg}$ słomy oraz jesienią zielona masa międzyplonu ścierniskowego z gorczycy białej w ilości 15-16 tha ${ }^{-1}$. Nawożenie mineralne fosforem (superfosfat wzbogacony-17,4\% P) i potasem (sól potasowa- $49,8 \% \mathrm{~K}$ ) w oparciu o zasobność gleby w przyswajalne formy tych składników stosowano wczesną wiosną przed rozpoczęciem zabiegów uprawowych w dawce 26,2 kg P.ha- ${ }^{-1}$ i 99,6 kg K'ha1. Nawożenie mineralne azotem (saletrzak-27\% N) stosowano wiosną przed sadzeniem bulw w dawce $100 \mathrm{~kg} \mathrm{~N} \cdot \mathrm{ha}^{-1}$.

Chwasty niszczono stosując do wschodów roślin ziemniaka 2-krotnie obsypnik z łańcuchami. Bezpośrednio przed wschodami, po ostatnim obredleniu zastosowano Linurex $500 \mathrm{SC}$ w dawce
$21 \cdot \mathrm{ha}^{-1}$ (2018 rok) oraz Proman 500 SC w dawce $41 \cdot \mathrm{ha}^{-1}$ (2019 rok), a po wschodach roślin ziemniaka w obydwu latach badań Titus 23 WG w dawce $60 \mathrm{~g} \cdot \mathrm{ha}^{-1}$. W okresie wegetacji 2018 roku zastosowano trzy zabiegi, a w 2019 roku dwa zabiegi przeciwko zarazie ziemniaka. $Z$ kolei przeciwko stonce w 2018 roku wykonano cztery, a w 2019 roku pięć zabiegów ochronnych.

Ziemniaki odmiany Oberon sadzono ręcznie w III dekadzie kwietnia w rozstawie $75 \times 33 \mathrm{~cm}$, a zbierano w III dekadzie września. Liczba roślin na poletku wynosiła 75. Podczas zbioru określono plon ogólny bulw z każdego poletka oraz pobierano 2 x 5-kilogramowe próby w celu określenia struktury plonu, udziału wagowego frakcji bulw o średnicy: poniżej $35 \mathrm{~mm}, 36-50 \mathrm{~mm}, 51-60 \mathrm{~mm}$ i powyżej $60 \mathrm{~mm}$ (Rozporządzenie 2003), procentowego udziału $\mathrm{w}$ plonie bulw $\mathrm{z}$ wadami wyglą$\mathrm{du}$ : zdeformowanych, zazielenionych, porażonych parchem zwykłym oraz składu chemicznego bulw: zawartości skrobi, azotanów, witaminy C i suchej masy. Zawartość skrobi oznaczono metodą Eversa (hydrolizę skrobi przeprowadzono we wrzącej łaźni wodnej, a następnie wytrącono białko przy pomocy kwasu fosforowo-wolframowego) z dokonaniem odczytów na automatycznym polarymetrze Polamat S. Azotany $\mathrm{NO}_{3}(\mathrm{~V})$ oznaczono metodą Griessa (z wykorzystaniem mieszaniny cynku i manganu przy redukcji azotanów do azotynów) z odczytem zawartości przy użyciu reflektomertu RQ Flex Merck. Zawartość witaminy C określono jako sumę kwasu L-askorbinowego i dehydroaskorbinowego metodą Tillmansa za pomocą miareczkowania roztworem 2,6-dwuchlorofenoloindofenolu. Zawartość suchej masy oznaczono metodą 2-stopniowego suszenia, w temperaturze 60 i $105^{\circ} \mathrm{C}$.

Wyniki doświadczeń opracowano statystycznie posługując się analizą wariancji. Analizę

Tabela 2

Table 2

Warunki pogodowe w latach badań na podstawie stacji meteorologicznej w Jadwisinie

Weather conditions in the investigation years on the base meteorological station in Jadwisin

\begin{tabular}{|c|c|c|c|c|c|c|c|}
\hline \multirow{2}{*}{$\begin{array}{l}\text { Year } \\
\text { Rok }\end{array}$} & \multicolumn{6}{|c|}{ Miesiąc / Month } & \multirow{2}{*}{$\begin{array}{l}\text { Suma / Średnia } \\
\text { Sum / Mean }\end{array}$} \\
\hline & IV & $\mathrm{V}$ & VI & VII & VIII & IX & \\
\hline \multicolumn{8}{|c|}{ Suma opadów (mm) / Sum of rainfalls (mm) } \\
\hline 2018 & 21,7 & 43,4 & 41,0 & 75,2 & 60,6 & 30,9 & 272,8 \\
\hline 2019 & 1,7 & 76,6 & 6,9 & 33,4 & 37,0 & 60,8 & 216,4 \\
\hline $1967-2017$ & 37,0 & 57,0 & 75,0 & 76,0 & 61,0 & 48,0 & 352,0 \\
\hline \multicolumn{8}{|c|}{ Średnia temperatura powietrza $\left({ }^{\circ} \mathrm{C}\right) /$ Mean air temperature $\left({ }^{\circ} \mathrm{C}\right)$} \\
\hline 2018 & 13,2 & 17,6 & 19,1 & 21,2 & 20,8 & 15,8 & 18,0 \\
\hline 2019 & 10,2 & 13,4 & 22,7 & 18,8 & 20,8 & 14,7 & 16,8 \\
\hline $1967-2017$ & 7,9 & 13,7 & 16,6 & 18,5 & 17,9 & 13,2 & 14,5 \\
\hline
\end{tabular}


porównania średnich przeprowadzono z wykorzystaniem testu Tukeya na poziomie $p=0,05$. Celem określenia źródeł zmienności badanych cech w zmienności całkowitej przeprowadzono ocenę komponentów wariancyjnych wykorzystując program Anova. Procentowy udział poszczególnych komponentów wariancyjnych posłużył do oceny wpływu preparatu i badanych lat oraz ich współdziałania na zmienność plonu i określonych cech jakości bulw ziemniaka.

\section{Wyniki i Dyskusja}

W badaniach uzyskano istotne zróżnicowanie plonu bulw pod wpływem zastosowanych preparatów biostymulujących $\mathrm{w}$ porównaniu do obiektu kontrolnego, bez dolistnego dokarmiania oraz pomiędzy latami (tabela 3). Niezależnie od badanych lat przyrost plonu bulw po zastosowaniu preparatu Naturamin WSP wyniósł 19\%, preparatu Krzemian stanowił $16,9 \%$, a pod wpływem preparatu Naturamin Plus uzyskano plon większy o 15,9\% w stosunku do obiektu kontrolnego. Wcześniejsze badania własne wykazały wzrost plonu bulw, średnio $\mathrm{w}$ latach o $13,8 \%$ pod wpływem biostymulatorów aminokwasowych - tecamin (Trawczyński
2014). Inni badacze wykazali również korzystne, ale bardzo zróżnicowane, od 3 do $36 \%$ oddziaływanie na wielkość plonu bulw ziemniaka biostymulatorów $\mathrm{z}$ aminokwasami uzyskiwanych na bazie różnych produktów (Matysiak i Adamczewski 2010, Mystkowska 2017 i 2018, Prajapati i in. 2016, Röder i in. 2018, Sarhan 2011). W stosunku do działania krzemu wcześniejsze badania własne wykazały wzrost plonu bulw o $9 \%$ po zastosowaniu dolistnym preparatu z kalcytu morskiego, Herbagreen Basic zawierającego 7,99\% tego pierwiastka (Trawczyński 2013). W odniesieniu do buraka cukrowego pod wpływem preparatu Herbagreen Basic zanotowano wzrost plonu korzeni średnio o $21 \%$ w porównaniu do obiektu kontrolnego (Artyszak i in. 2016). W badaniach holenderskich po zastosowaniu dolistnym kwasu krzemowego uzyskano przyrost plonu bulw o $6,5 \% \mathrm{w}$ stosunku do obiektu kontrolnego (Laane 2017). W badaniach Crusciola i in. (2009) w warunkach stresu suszy po zastosowaniu krzemianu wapnia i magnezu wykazano wzrost plonu bulw o 11,4\% w stosunku do obiektu kontrolnego. Z kolei Ryakhovskaya i in. (2016) po zastosowaniu preparatów krzemowych w różnej formie: płynnej, żelu jak i proszku stwierdzili przyrost plonu

Wpływ dolistnego dokarmiania na plon bulw $\left(\mathrm{t} \cdot \mathrm{ha}^{-1}\right)$ i strukturę plonu (\%)

The effect of foliar fertilization on yield of tubers $\left(\mathrm{t} \cdot \mathrm{ha}^{-1}\right)$ and yield of structure $(\%)$

\begin{tabular}{c|c|c|c|c|c}
\hline \multirow{2}{*}{$\begin{array}{c}\text { Obiekt i lata } \\
\text { Object and years }\end{array}$} & \multirow{2}{*}{$\begin{array}{c}\text { Plon bulw } \\
\text { Yield of tubers }\end{array}$} & \multicolumn{4}{|c}{ Udział frakcji bulw $(\mathrm{mm})$} \\
\cline { 3 - 6 } & & $<35$ & $36-50$ & $51-60$ & $>60$ \\
\hline Obiekt kontrolny* & $41,5 \mathrm{~b}$ & $1 \mathrm{~b}$ & $28 \mathrm{a}$ & $31 \mathrm{a}$ & $40 \mathrm{a}$ \\
Krzemian & $48,5 \mathrm{a}$ & $2 \mathrm{a}$ & $25 \mathrm{a}$ & $30 \mathrm{a}$ & $43 \mathrm{a}$ \\
Naturamin Plus & $48,1 \mathrm{a}$ & $1 \mathrm{~b}$ & $27 \mathrm{a}$ & $31 \mathrm{a}$ & $41 \mathrm{a}$ \\
Naturamin WSP & $49,4 \mathrm{a}$ & $1 \mathrm{~b}$ & $26 \mathrm{a}$ & $29 \mathrm{a}$ & $44 \mathrm{a}$ \\
2018 & $52,9 \mathrm{a}$ & $1 \mathrm{~b}$ & $29 \mathrm{a}$ & $36 \mathrm{a}$ & $34 \mathrm{~b}$ \\
2019 & $40,8 \mathrm{~b}$ & $2 \mathrm{a}$ & $23 \mathrm{~b}$ & $25 \mathrm{~b}$ & $50 \mathrm{a}$ \\
Obiekt kontrolny*/2018 & $46,6 \mathrm{~b}$ & $1 \mathrm{~b}$ & $29 \mathrm{a}$ & $36 \mathrm{ab}$ & $34 \mathrm{a}$ \\
Krzemian/2018 & $54,8 \mathrm{a}$ & $2 \mathrm{a}$ & $29 \mathrm{a}$ & $33 \mathrm{~b}$ & $36 \mathrm{a}$ \\
Naturamin Plus/2018 & $54,5 \mathrm{a}$ & $1 \mathrm{~b}$ & $30 \mathrm{a}$ & $38 \mathrm{a}$ & $31 \mathrm{a}$ \\
Naturamin WSP/2018 & $55,8 \mathrm{a}$ & $1 \mathrm{~b}$ & $27 \mathrm{a}$ & $37 \mathrm{a}$ & $35 \mathrm{a}$ \\
Obiekt kontrolny*/2019 & $36,4 \mathrm{~b}$ & $2 \mathrm{~b}$ & $26 \mathrm{a}$ & $25 \mathrm{ab}$ & $47 \mathrm{~b}$ \\
Krzemian/2019 & $42,2 \mathrm{a}$ & $1 \mathrm{c}$ & $21 \mathrm{~b}$ & $28 \mathrm{a}$ & $50 \mathrm{ba}$ \\
Naturamin Plus/2019 & $41,6 \mathrm{a}$ & $3 \mathrm{a}$ & $22 \mathrm{~b}$ & $25 \mathrm{ab}$ & $50 \mathrm{ba}$ \\
Naturamin WSP/2019 & $43,1 \mathrm{a}$ & $3 \mathrm{a}$ & $22 \mathrm{~b}$ & $21 \mathrm{~b}$ & $54 \mathrm{a}$ \\
\hline \multicolumn{5}{c}{ Udział w wariancji całkowitej/ Share in total variance (\%) } \\
\hline Preparat/Formula (1) & 8,1 & 1,4 & 4,2 & 0,7 & 1,4 \\
Lata/Years (2) & 91,6 & 70,2 & 91,0 & 95,8 & 97,5 \\
(1x2) & 0,3 & 28,4 & 4,8 & 3,5 & 1,1 \\
\hline
\end{tabular}

*Control object; Średnie z tymi samymi literami nie różnią się istotnie / Means with the same letter do not differ significantly. 
bulw od 10,7 do $20,3 \%$ w porównaniu do obiektu kontrolnego. Natomiast w badaniach Wróbla (2012) dolistny preparat krzemowy Actisil nie spowodował wzrostu plonu bulw ziemniaka w stosunku do obiektu kontrolnego. Na podstawie oceny komponentów wariancyjnych wykazano, że dominujący wpływ na zmienność plonu bulw miały warunki pogodowe w latach $(91,6 \%)$, a udział preparatu stanowił tylko $8,1 \%$. Podobnie, największy udział lat w gromadzeniu plonu bulw stwierdziła Sawicka i in. (2011). Niezależnie od obiektów z dolistnym dokarmianiem istotnie większy plon bulw uzyskano w 2018 roku, suchym i bardzo gorącym, niż w 2019 roku, bardzo suchym i mniej upalnym. Różnica w plonie bulw pomiędzy latami stanowiła $22,9 \%$. Wskazywało to, że większy wpływ na plonowanie ziemniaka miały opady, niż temperatura powietrza w okresie wegetacji, co potwierdziła również Mystkowska (2018). Ogólnie korzystniejszy efekt dolistnego dokarmiania badanymi preparatami uzyskano $\mathrm{w}$ roku upalnym, ale $\mathrm{z}$ mniejszym deficytem opadów, co wyrażało się wzrostem od 1,7 do $2,6 \%$ w stosunku do roku z większym niedoborem opadów i mniej upalnym. Na ogół lepsze oddziaływanie preparatów biostymulujących na plonowanie stwierdza się w latach o niekorzystnym układzie warunków pogodowych $\mathrm{w}$ okresie wegetacji roślin, głównie związanych z nadmiarem lub niedoborem opadów oraz większą od średniej $\mathrm{z}$ wielolecia temperaturą powietrza (Artyszak i in. 2014, Mystkowska 2018, Trawczyński 2013 i 2014). Wierzbowska i in. (2015) wykazali w warunkach nadmiaru opadów i wysokiej temperatury powietrza wzrost plonu bulw pod wpływem zabiegów dolistnych biostymulatorami, średnio o $20 \% \mathrm{w}$ porównaniu do obiektu kontrolnego. Podobnie Cwalina-Ambroziak i in. (2015) wykazali korzystne oddziaływanie biostymulatorów dolistnych na plon bulw w warunkach presji infekcyjnej zarazy ziemniaka wynikającej z nadmiaru opadów.

W badaniach stwierdzono mniejsze, w porównaniu do wielkości plonu zróżnicowanie frakcji bulw. Niezależnie od badanych lat pod wpływem dolistnego dokarmiania preparatami biostymulującymi w stosunku do obiektu kontrolnego wykazano tendencję malejącą frakcji bulw o średnicy $36-50 \mathrm{~mm}$ oraz tendencję wzrostu udziału w strukturze plonu bulw dużych, o średnicy powyżej $60 \mathrm{~mm}$ (tabela 3). Analizując współdziałanie wykazano, że tylko w drugim roku badań uzyskano istotnie mniej bulw frakcji $36-50 \mathrm{~mm}$ po zastosowaniu preparatów w porównaniu do obiektu kontrolnego oraz istotnie więcej bulw dużych, o średnicy powyżej $60 \mathrm{~mm}$ pod wpływem preparatu Naturamin WSP w stosunku do obiektu kontrolnego. Natomiast istotne zróżnicowanie wszystkich frakcji bulw stwierdzono pomiędzy latami badań. W pierwszym roku badań, o mniejszym deficycie opadów uzyskano istotnie więcej bulw frakcji $36-50 \mathrm{~mm}$ oraz frakcji 51-60 $\mathrm{mm}$, natomiast $\mathrm{w}$ roku o większym niedoborze opadów większy udział w strukturze plonu bulw dużych, o średnicy powyżej $60 \mathrm{~mm}$. Wynikać to mogło z mniejszej ilości zawiązanych bulw w roku bardzo suchym i w efekcie końcowym dorastania bulw do większej średnicy. W dotychczas przeprowadzonych badaniach uzyskano korzystne oddziaływanie dolistnego dokarmiania preparatem krzemowym na strukturę plonu bulw głównie poprzez istotne zmniejszenie udziału frakcji bulw małych, o średnicy poniżej $30 \mathrm{~mm}$ (Wróbel 2012). Z kolei Głosek-Sobieraj i in. (2017) po zastosowaniu biostymulatorów dolistnych wykazali wzrost udziału w strukturze plonu bulw o średnicy 36-50 mm, a Baranowska i in. (2019) frakcji bulw o średnicy powyżej $50 \mathrm{~mm}$. W przeprowadzonych badaniach, podobnie jak w stosunku do uzyskanego plonu bulw wykazano największy wpływ na strukturę plonu bulw warunków pogodowych w latach, który wahał się w zmienności całkowitej od 70,2\% w przypadku bulw małych o średnicy poniżej $35 \mathrm{~mm}$ do $97,5 \%$ dla bulw o średnicy powyżej $60 \mathrm{~mm}$. Udział preparatu w całkowitej zmienności największy był w stosunku do bulw o średnicy $36-50 \mathrm{~mm}$, a współdziałania preparatu z latami w przypadku bulw o średnicy poniżej $35 \mathrm{~mm}$.

Pod wpływem zastosowanych biostymulatorów, spośród ocenianych wad zewnętrznych istotne zróżnicowanie uzyskano tylko w stosunku do udziału w plonie bulw zdeformowanych (tabela 4). Średnio w latach, istotnie najmniejszy udział w plonie bulw zdeformowanych uzyskano po zastosowaniu biostymulatora Naturamin WSP oraz większą w porównaniu do pozostałych obiektów tendencję malejącą udziału sumy wad w plonie. Tendencję malejącą udziału w plonie bulw zdeformowanych i zazielenionych pod wpływem zastosowanych biostymulatorów aminokwasowych wykazano również we wcześniejszych badaniach własnych (Trawczyński 2014). Analizując oddziaływanie preparatów w poszczególnych latach wykazano tendencję malejącą sumy wad bulw w roku suchym oraz rosnącą $\mathrm{w}$ roku bardzo suchym w stosunku do obiektu kontrolnego. Niezależnie od zastosowanych biostymulatorów, w roku suchym uzyskano istotnie więcej bulw zazielenionych, natomiast w roku bardzo suchym bulw porażonych parchem zwykłym. Większy udział bulw zazielenionych wynikać mógł z większej masy uzyskanego plonu 
Wpływ dolistnego dokarmiania na udział w plonie bulw z wadami wyglądu (\%)

The effect of foliar fertilization on share in yield of tubers with defects (\%)

\begin{tabular}{c|c|c|c|c}
\hline $\begin{array}{c}\text { Obiekt } \\
\text { Object }\end{array}$ & $\begin{array}{c}\text { Zdeformowane } \\
\text { Deformations }\end{array}$ & $\begin{array}{c}\text { Zazielenione } \\
\text { Greenings }\end{array}$ & $\begin{array}{c}\text { Parch zwykly } \\
\text { Common scab }\end{array}$ & $\begin{array}{c}\text { Suma wad } \\
\text { Sum of defects }\end{array}$ \\
\hline Obiekt kontrolny* & $9,1 \mathrm{ba}$ & $3,0 \mathrm{a}$ & $2,5 \mathrm{a}$ & $14,6 \mathrm{a}$ \\
Krzemian & $10,2 \mathrm{a}$ & $3,0 \mathrm{a}$ & $2,4 \mathrm{a}$ & $15,6 \mathrm{a}$ \\
Naturamin Plus & $9,1 \mathrm{ba}$ & $3,6 \mathrm{a}$ & $2,4 \mathrm{a}$ & $15,1 \mathrm{a}$ \\
Naturamin WSP & $8,5 \mathrm{~b}$ & $3,5 \mathrm{a}$ & $2,4 \mathrm{a}$ & $14,4 \mathrm{a}$ \\
2018 & $8,9 \mathrm{a}$ & $4,0 \mathrm{a}$ & $2,2 \mathrm{~b}$ & $15,1 \mathrm{a}$ \\
2019 & $9,6 \mathrm{a}$ & $2,5 \mathrm{~b}$ & $2,7 \mathrm{a}$ & $14,8 \mathrm{a}$ \\
Obiekt kontrolny*/2018 & $10,1 \mathrm{a}$ & $3,3 \mathrm{~b}$ & $2,5 \mathrm{a}$ & $15,9 \mathrm{a}$ \\
Krzemian/2018 & $9,2 \mathrm{ba}$ & $3,9 \mathrm{ba}$ & $2,2 \mathrm{ba}$ & $15,3 \mathrm{a}$ \\
Naturamin Plus/2018 & $8,0 \mathrm{~b}$ & $4,6 \mathrm{ba}$ & $2,0 \mathrm{~b}$ & $14,6 \mathrm{a}$ \\
Naturamin WSP/2018 & $8,1 \mathrm{~b}$ & $4,3 \mathrm{a}$ & $2,0 \mathrm{~b}$ & $14,4 \mathrm{a}$ \\
Obiekt kontrolny */2019 & $8,2 \mathrm{~b}$ & $2,7 \mathrm{a}$ & $2,5 \mathrm{a}$ & $13,4 \mathrm{~b}$ \\
Krzemian/2019 & $11,3 \mathrm{a}$ & $2,1 \mathrm{~b}$ & $2,6 \mathrm{a}$ & $16,0 \mathrm{a}$ \\
Naturamin Plus/2019 & $10,2 \mathrm{ba}$ & $2,7 \mathrm{a}$ & $2,8 \mathrm{a}$ & $15,7 \mathrm{a}$ \\
Naturamin WSP/2019 & $8,9 \mathrm{ba}$ & $2,7 \mathrm{a}$ & $2,8 \mathrm{a}$ & $14,4 \mathrm{ba}$ \\
\hline \multicolumn{5}{c}{ Udział w wariancji całkowitej / Share in total variance (\%) } \\
\hline Preparat/Formula (1) & 25 & 4,6 & 1,0 & 2,7 \\
Lata/Years (2) & 30 & 92,0 & 98,9 & 32,0 \\
$(1 \times 2)$ & 45 & 3,4 & 0,1 & 65,3 \\
\hline
\end{tabular}

*Control object; Średnie z tymi samymi literami nie różnią się istotnie / Means with the same letter do not differ significantly.

bulw w 2018 roku, a większy udział bulw porażonych parchem zwykłym z bardzo dużego niedoboru opadów w okresie tuberyzacji (czerwiec) w 2019 roku. Wykazano, że warunki pogodowe w latach najbardziej kształtowały zazielenienia i porażenie bulw parchem zwykłym, odpowiednio 92 i 98,9\%, natomiast udział bulw zdeformowanych i sumę wad w plonie współdziałanie lat $\mathrm{z}$ zastosowanymi biostymulatorami. Podobnie wysoki wpływ warunków meteorologicznych na udział w plonie bulw z wadami wyglądu, w tym zdeformowanych wykazały w badaniach Lutomirska i Jankowska (2012).

Analizując skład chemiczny bulw w stosun$\mathrm{ku}$ do zastosowanych biostymulatorów wykazano istotne zróżnicowanie wszystkich składników w porównaniu do obiektu kontrolnego (tabela 5). Średnio w latach uzyskano istotnie większą zawartość skrobi w bulwach, szczególnie po zastosowaniu preparatów Naturamin Plus i Krzemian w stosunku do obiektu kontrolnego. Podobnie Mystkowska (2019) stwierdziła istotnie dodatni wpływ różnego rodzaju biostymulatorów dolistnych na zawartość skrobi w bulwach. Z kolei we wcześniejszych badaniach własnych nie wykazano zmian zawartości skrobi w bulwach po zastosowaniu biostymulatorów aminokwasowych w porównaniu do obiektu kontrolnego (Trawczyński 2014). Zmiany zawartości skrobi w bulwach pod wpływem zastosowanych biostymulatorów zbieżne były z zawartością suchej masy (tabela 5). Niezależnie od badanych lat, wszystkie zastosowane biostymulatory przyczyniły się do istotnego wzrostu zawartości witaminy $\mathrm{C} \mathrm{w}$ bulwach. Istotnie największy poziom tego składnika uzyskano po zastosowaniu preparatu Naturamin WSP (tabela 5). Z kolei pod wpływem preparatu Krzemian uzyskano istotne obniżenie poziomu azotanów w bulwach, zarówno w stosunku do obiektu kontrolnego, jak i pozostałych biostymulatorów. W badaniach Wróbla (2012) również wykazano istotne obniżenie zawartości azotanów (V) w bulwach po zastosowaniu preparatu krzemowego Actisil w stosunku do obiektu kontrolnego. Natomiast biostymulatory aminokwasowe przyczyniły się do większej zawartości azotanów (V) w bulwach w stosunku do obiektu kontrolnego (Trawczyński 2014). Istotne zróżnicowanie oznaczonych składników uzyskano również w stosunku do lat badań. Większy poziom skrobi i suchej masy uzyskano w 2019 roku, z większym niedoborem opadów i niższą temperaturą powietrza niż w 2018 
Wpływ dolistnego dokarmiania na skład chemiczny bulw ziemniaka

The effect of foliar fertilization on chemical composition of potato tubers

\begin{tabular}{c|c|c|c|c}
\hline $\begin{array}{c}\text { Obiekt } \\
\text { Object }\end{array}$ & $\begin{array}{c}\text { Skrobia } \\
\text { Starch } \\
\mathrm{g} \cdot \mathrm{kg}^{-1}\end{array}$ & $\begin{array}{c}\text { Azotany (V) } \\
\text { Nitrates (V) } \\
\mathrm{mg} \cdot \mathrm{kg}^{-1}\end{array}$ & $\begin{array}{c}\text { Witamina C } \\
\text { Vitamin C } \\
\mathrm{mg} \cdot \mathrm{kg}^{-1}\end{array}$ & $\begin{array}{c}\text { Sucha masa } \\
\text { Dry matter } \\
\mathrm{g} \cdot \mathrm{kg}^{-1}\end{array}$ \\
\hline Obiekt kontrolny* & $122 \mathrm{c}$ & $94 \mathrm{~b}$ & $227 \mathrm{~d}$ & $188 \mathrm{c}$ \\
Krzemian & $132 \mathrm{a}$ & $82 \mathrm{c}$ & $236 \mathrm{~b}$ & $198 \mathrm{a}$ \\
Naturamin Plus & $133 \mathrm{a}$ & $107 \mathrm{a}$ & $234 \mathrm{c}$ & $197 \mathrm{a}$ \\
Naturamin WSP & $126 \mathrm{~b}$ & $108 \mathrm{a}$ & $240 \mathrm{a}$ & $191 \mathrm{~b}$ \\
2018 & $119 \mathrm{~b}$ & $132 \mathrm{a}$ & $239 \mathrm{a}$ & $184 \mathrm{~b}$ \\
2019 & $138 \mathrm{a}$ & $63 \mathrm{~b}$ & $230 \mathrm{~b}$ & $203 \mathrm{a}$ \\
Obiekt kontrolny */2018 & $119 \mathrm{a}$ & $108 \mathrm{~b}$ & $231 \mathrm{~d}$ & $184 \mathrm{a}$ \\
Krzemian/2018 & $119 \mathrm{a}$ & $108 \mathrm{~b}$ & $241 \mathrm{~b}$ & $184 \mathrm{a}$ \\
Naturamin Plus/2018 & $119 \mathrm{a}$ & $155 \mathrm{a}$ & $240 \mathrm{a}$ & $185 \mathrm{a}$ \\
Naturamin WSP/2018 & $118 \mathrm{a}$ & $160 \mathrm{a}$ & $243 \mathrm{c}$ & $185 \mathrm{a}$ \\
Obiekt kontrolny */2019 & $126 \mathrm{c}$ & $81 \mathrm{a}$ & $223 \mathrm{~d}$ & $192 \mathrm{~d}$ \\
Krzemian/2019 & $146 \mathrm{a}$ & $56 \mathrm{~b}$ & $231 \mathrm{~b}$ & $213 \mathrm{a}$ \\
Naturamin Plus/2019 & $146 \mathrm{a}$ & $59 \mathrm{~b}$ & $229 \mathrm{c}$ & $209 \mathrm{~b}$ \\
Naturamin WSP/2019 & $134 \mathrm{~b}$ & $57 \mathrm{~b}$ & $238 \mathrm{a}$ & $198 \mathrm{c}$ \\
\hline \multicolumn{5}{c}{ Udział w wariancji całkowitej/ Share in total variance (\%) } \\
\hline Preparat/Formula (1) & 6,0 & 2,9 & 29,3 & 6,3 \\
Lata/Years (2) & 88,2 & 91,0 & 69,3 & 87,8 \\
$(1 \times 2)$ & 5,8 & 6,1 & 1,4 & 5,9 \\
\hline
\end{tabular}

*Control object; Średnie z tymi samymi literami nie różnią się istotnie / Means with the same letter do not differ significantly.

roku, natomiast odwrotną zależność w stosunku do zawartości azotanów i witaminy $\mathrm{C}$ w bulwach. $\mathrm{Z}$ badań różnych autorów również wynikało, że lata suche sprzyjały wzrostowi witaminy $\mathrm{C}$ w bulwach (Gąsiorowska i Zarzecka 2002, Kraska 2002, Mazurczyk i Lis 2004). Lata suche $\mathrm{z}$ większą temperaturą powietrza oddziaływały również korzystniej niż lata wilgotne i chłodne na gromadzenie suchej masy i skrobi w bulwach (Kołodziejczyk i Szmigiel 2012, Rymuza i in. 2015). Ekstremalnie wysokie temperatury jakie zanotowano w okresie wegetacji 2018 roku miały jednak istotnie ujemny wpływ na gromadzenie tych składników w bulwach w porównaniu do 2019 roku. Natomiast lata z niedoborem opadów i wysoką temperaturą powietrza mogą być przyczyną nadmiernego gromadzenia azotanów (V) w bulwach, o czym donosiły Grudzińska i Zgórska (2008). W przeprowadzonych badaniach wykazano, że szczególnie niekorzystny wpływ, poprzez istotny wzrost kumulacji azotanów (V) w bulwach miał suchy okres wegetacji z ekstremalnie wysoką temperaturą powietrza. Na podstawie analizy komponentów wariancyjnych wykazano, że w największym stopniu zawartość wszystkich składników, od $69,3 \% \mathrm{w}$ przypadku zawartości witaminy
C do $91 \%$ w odniesieniu do poziomu azotanów (V) w bulwach kształtowały lata badań, natomiast największy udział preparatu zaznaczył się we wpływie na zawartość witaminy $\mathrm{C}$ w bulwach.

\section{Wnioski}

1. Pod wpływem badanych biostymulatorów uzyskano istotny przyrost plonu oraz korzystniejsze oddziaływanie na zawartość składników pokarmowych w bulwach w porównaniu do obiektu kontrolnego.

2. Korzystniejszy efekt plonowania pod wpływem zastosowanych biostymulatorów uzyskano w pierwszym roku, o mniejszym deficycie opadów i większej temperaturze powietrza w porównaniu do drugiego roku badań.

3. Znacznie większy wpływ na kształtowanie wielkości plonu i cech jakości bulw miały warunki pogodowe w latach niż oddziaływanie preparatów.

\section{Literatura}

Artyszak A., Gozdowski D., Kucińska K. 2014. The effect of foliar fertilization with marine calcite in sugar beet. Plant Soil Environ. 60: 413 - 417. 
Artyszak A., Gozdowski D., Kucińska K. 2016. The effect of calcium and silicon foliar fertilization in sugar beet. Sugar Technol. 18(1): $109-114$.

Baranowska A., Mystkowska I., Szczygielska E. 2019. Impact of growth biostimulators and herbicide on the yield structure of edible potato tubers (Solanum tuberosum L.). Acta Agrophysica 26(1): $25-36$.

Colla G., Rouphael Y., Lucini L., Canaguier R., Stefanoni W., Fiorillo A., Cardarelli M. 2015. Protein hydrolysate-based biostimulants: origin, biological activity and application methods. [In:] II World Congress on the Use of Biostimulants in Agriculture 1148: $27-34$.

Crusciol C.A.C., Pulz A.L., Lemos L.B., Soratto R.P., Lima G.P.P. 2009. Effects of silicon and drought stress on tuber yield and leaf biochemical characteristics in potato. Crop Science 49: 949 - 954.

Cwalina-Ambroziak B., Głosek-Sobieraj M., Kowalska E. 2015. The effect of plant growth regulators on the incidence and severity of potato diseases. Pol. J. Natural Sci. 30(1): $5-20$.

Du Jardin P. 2015. Plant biostimulants: definition, concept, main categories and regulation. Sci. Hortic. 196: 3- 14 .

Ertani A., Schiavon M., Altissimo A., Franceschi C., Nardi S. 2011. Phenol-containing organic substances stimulate phenylpropanoid metabolism in Zea mays. J. Plant Nutr. Soil Sci. 174(3): 496 - 503.

Erlichowski T., Pawińska M. 2003. Biologiczna ocena preparatu Kelpak w ziemniaku. Prog. Plant Prot. 43(2): $606-609$.

Fauteux F., Rémus-Borel W., Menzies J. G., Bélanger R. R. 2005. Silicon and plant disease resistance against pathogenic fungi. FEMS Microbiology Letters, 249: $1-6$.

Gąsiorowska B., Zarzecka K. 2002. Wpływ terminu zbioru na plon i cechy jakościowe bulw ziemniaka uprawianego w rejonie Siedlec. - Zesz. Probl. Post. Nauk Rol. 489: $319-325$.

Głosek-Sobieraj M., Cwalina-Ambroziak B., Hamouz K. 2017. The effect of growth regulators and a biostimulator on the health status, yield and yield components of potatoes (Solanum tuberosum L.). Gesunde Pflanzen 70: $1-11$.

Górecki R. S., Danielski-Busch W. 2009. Effect of silicate fertilizers on yielding of greenhouse cucumber (Cucumis sativus L.) in container cultivation. J. Elementol. 14(1): $71-78$.

Grudzińska M., Zgórska K. 2008. Wpływ warunków meteorologicznych na zawartość azotanów (V) w bulwach ziemniaka. Żywn. Nauka. Technol. Jakość, 5 (60): $98-106$.

Kołodziejczyk M., Szmigiel A. 2012. Skład chemiczny oraz wybrane parametry jakości bulw ziemniaka w zależności od terminu i stopnia redukcji powierzchni asymilacyjnej roślin. Fragm. Agronom. 29(3): 88 - 94.

Kraska P. 2002. Wpływ sposobów uprawy, poziomów nawożenia i ochrony na wybrane cechy jakości ziemniaka.
Zesz. Probl. Post. Nauk Roln. 489: 229 — 237.

Laane H. M. 2017. The effects of the application of foliar sprays with stabilized silicic acid: An overview of the results from 2003-2014. Silicon, 9: 803 - 807.

Lutomirska B., Jankowska J. 2012. Występowanie deformacji i spękań bulw ziemniaka w zależności od warunków meteorologicznych i odmiany. Biul. IHAR 266: $131-142$.

Marcinek J., Komisarek J., Bednarek R., Mocek A., Skiba S., Wiatrowska K. 2011. Systematyka Gleb Polski. Roczn. Glebozn. 62 (3): $91-147$.

Matysiak K., Adamczewski K., 2010. Wpływ regulatora wzrostu i rozwoju roślin Moddus 250 EC, Kelpak SL, Algaminoplant, Humiplant i Yeald Plus na plonowanie i wielkość bulw ziemniaka. Ziem. Polski, 1: 28 - 33 .

Mazurczyk W., Lis B. 2004. Relacje między zawartością witaminy $\mathrm{C}$ i azotanów w bulwach różnych odmian ziemniaka. Biul. IHAR 232: $47-52$.

Mitani N., Ma J. F. 2005. Uptake system of silicon in different plant species. J. Experimental Botany 56: 1255 - 1261.

Mystkowska I. 2017. Wpływ zróżnicowanej techniki odchwaszczania i stosowania biostymulatorów na efektywność ekonomiczną uprawy ziemniaków jadalnych. Rocz. Nauk. SERiA 19(6): $190-194$.

Mystkowska I. 2018. Biostymulatory jako czynnik wpływający na plon ziemniaka jadalnego. Acta Agroph. 25(3): $307-315$.

Mystkowska I. 2019. Wpływ stosowania biostymulatorów na zawartość suchej masy i skrobi w bulwach ziemniaka. Fragm. Agronom. 36(1): $45-53$.

Popko M., Michalak I., Wilk R., Gramza M., Chojnacka K., Górecki H. 2018. Effect of the new plant growth biostimulants based on amino acids on yield and grain quality of winter wheat. - Molecules 23(2): 470.

Prajapati A., Patel C. K., Singh N., Jain S. K., Chongtham S. K., Maheshwari M. N., Patel R. N. 2016. Evaluation of seaweed extract on growth and yield of potato. - Environ. Ecol. 34(2): $605-608$.

Raven J. A. 2003. Cycling silicon - The role of accumulation in plants. New Phytology 158: $419-421$.

Romero-Aranda M. R., Jurado O., Cuartero J. 2006. Silicon alleviates the deleterious salt effect on tomato plant growth by improving plant water status. J. Plant Physiol. 163: $847-855$.

Röder C., Mógor Á. F., Szilagyi-Zecchin V. J., Gemin L. G., Mógor G. 2018. Potato yield and metabolic changes by use of biofertilizer containing L-glutamic acid. - Comun. Sci. 9(2): $211-218$.

Rozporządzenie 2003. Rozporządzenie Ministra Rolnictwa i Rozwoju Wsi z dnia 29 grudnia 2003 roku w sprawie szczegółowych wymagań w zakresie jakości handlowej ziemniaków. Dz. U. Nr 194, poz. 1900.

Ryakhovskaya N. I., Gaynatulina V. V., Makarova M. A. 2016. Effectiveness of potato cultivation using nanosized silica 
under conditions of Kamchatka Krai. Russian Agric. Sci. 42: $299-303$.

Rykaczewska K. 2013. The impact of high temperature during growing season on potato cultivars with different response to environmental stresses. Am. J. Plant Sci. 4: 2386 - 2393.

Rymuza K., Radzka E., Lenartowicz T. 2015. Wpływ warunków środowiskowych na zawartość skrobi w bulwach odmian ziemniaka średnio wczesnego. Acta Agroph. 22(3): $279-289$.

Sacała E. 2009. Role of silicon in plant resistance to water stress. J. Elementol. 14: 619 - 630.

Sarhan T. Z. 2011. Effect of humic acid and seaweed extracts on growth and yield of potato plant (Solanum tubersum L.) Desiree cv. Mesopotamia J. Agric. 39(2): $19-25$.

Sawicka B., Michałek W., Pszczółkowski P. 2011. Uwarunkowania potencjału plonowania średnio późnych i późnych odmian ziemniaka w warunkach środkowo - wschodniej Polski. Biul. IHAR 259: $219-228$.

Sharma H. S., Fleming C., Selby C., Rao J. R., Martin T. 2014. Plant biostimulants: a review on the processing of macroalgae and use of extracts for crop management to reduce abiotic and biotic stresses. J. Appl.Phycology 26(1): $465-490$.
Sommer M., Kaczorek D., Kuzyakov Y., Breuer J. 2006. Silicon pools and fluxes in soils and landscapes - A review. J. Plant Nutrition Soil Sci. 169: 310 - 329.

Stamatakis A., Papadantonakis N., Lydakis-Simantiris N., Kefalas P., Savvas D. 2003. Effects of silicon and salinity on fruit yield and quality of tomato grown hydroponically. Acta Horticulturae 609: 141 - 147.

Trawczyński C. 2013. Wpływ dolistnego nawożenia preparatem Herbagreen na plonowanie ziemniaków. Ziem. Polski 2: $29-33$.

Trawczyński C. 2014. Wpływ biostymulatorów aminokwasowych-tecamin na plon i jakość ziemniaków. Ziem. Polski 3: $29-34$.

Ugrinović M., Oljača S., Brdar-Jokanović M., Zdravković J., Girek Z., Zdravković M. 2011. The effect of liquid and soluble fertilizers on lettuce yield. Serb. J. Agric. Sci. 60: $110-115$.

Wierzbowska J., Cwalina-Ambroziak B., Głosek M., Sienkiewicz S. 2015. Effect of biostimulators on yield and selected chemical properties of potato tubers. J. Elemntol. 20: $757-768$.

Wróbel S. 2012. Wpływ nawożenia ziemniaka odmiany Jelly dolistnymi preparatami YaraVita Ziemniak oraz Actisil na plon i cechy jego jakości. Biul. IHAR 266: 295 - 306. 
